\title{
Cannabis sativa: A systematic review of plant analysis
}

\author{
Bruna Tassi Borille $^{\mathrm{a}^{*}}$; Marina González ${ }^{\mathrm{a}}$; Luiza Steffens ${ }^{\mathrm{a}}$; Rafael Scorsatto Ortiz ${ }^{\mathrm{b}}$; Renata Pereira Limberger ${ }^{\mathrm{a}}$ \\ ${ }^{a}$ Laboratório de Análises e Pesquisa em Toxicologia, Universidade Federal do Rio Grande do Sul, Departamento de \\ Farmácia, Porto Alegre, 90610-000, RS, Brazil. \\ ${ }^{b}$ Divisão Técnico-Científica do Rio Grande do Sul, Polícia Federal Brasileira, Porto Alegre, 90160-092, RS, Brazil. \\ *Corresponding author e-mail: bruhhtb@gmail.com
}

\begin{abstract}
Background: Cannabis has been the most widely used illicit drug worldwide throughout many years. Reports from different countries indicate that the potency of cannabis preparation has been increasing, as well as the ratio of tetrahydrocannabinol/cannabidiol has been changing. The high consumption couple with the variable chemical profile of the drug is increasing gradually the interest in researching the cannabis plant. Methods: This article reviews available literature on the analytical methods currently used for the detection and quantification of cannabinoids in cannabis plant. The papers were screened by two independently researchers and following a pre-specified protocol. Results and Discussion: The systematic review of the literature allowed to include 42 citations on cannabis plant analysis and botanical aspects of cannabis. Conclusions: The analytical methods for cannabis material published in the included articles of this systematic review showed lack of relevant information of the development of methods on GC and LC analysis and the limits of detection and quantification of mass detectors. These information, on the methods of analysis, are essential and extremely important, since in the current scenario the analytical approach should consider the action of modulation CBD with THC, which alters the disruptive effects of the drug and also presents important pharmacological activity.
\end{abstract}

Keywords: Cannabis sativa, marijuana, cannabinoids detection, plant analysis and analytical methods.

\section{Introduction}

Cannabis sativa L. (cannabis) remains the most widely cultivated, produced, trafficked and consumed drug worldwide $(1,2)$. At the same time, the plant has been used over the centuries for medicinal purposes (25), which results in controversial perception and opinion on its use. According to the "World Drug Report" published by UNODC (1), in the previous year, cannabis market development yielded an increased in the global seizures of $2 \%$ on cannabis resin and $4 \%$ on cannabis herb, which led to seizures of 1.433 and 5.834 tons, respectively.

Cannabis has over 500 identified chemicals in plant and around 100 of them are classified as (phyto) cannabinoids $(5,6)$. Analyses of the cannabinoids content and chemical profile in cannabis plants are extremely relevant, because both the medicinal effects and the adverse health effects may be associated with the potency and/or interplay of certain cannabinoids and other compounds (such as terpenoids) due to cannabis consumption $(4,5)$. In relation to forensic interest, the cannabinoids data may also assist in developing classification models to chemotypes, on distinction of the varieties, in establishing the growth period of the plant and in drug trafficking restraint $(5,7,8)$.

Although there are currently several wellestablished methods available for chemical analyses of cannabinoids (9-11), the high variability of cannabis samples become the chemical profile interpretation very difficult. There is a need for adaptations of traditional methods of cannabis analysis in light of new scientific evidence regarding the plant and its plant metabolites, taking into account the pharmacological activity as a potential drug and as a drug of abuse for recreational use. The instrumental analysis that have been commonly used to analyze cannabinoids are gas chromatography (GC) and liquid chromatography (LC) $(3,12)$. The use of GC, generally coupled to flame ionization detection (FID) $(9,11)$ or mass spectrometry (MS) detection, allows the analysis of a large variety of cannabinoids with high resolution $(8,10,13)$. For analyzing cannabinoids in their acid forms, LC is the preferred method. In addition, the compounds can be efficiently screened using ultraviolet (UV) or photodiode-array (PDA) detector $(11,14)$. Other methods have been used, as the genetic profile analysis (12). A genetic analysis, e. g. real-time polymerase chain reation (PCR), is an alternative method to chemical analysis, to examine forensic samples of cannabis in order to determine the tetrahydrocannabinol (THC) content $(15,16)$.

A systematic review becomes important during the process of realization of a survey, since, before starting the practical part, it is fundamental to design the analysis based on already performed methods for that type of research. Thus, this study aims to conduct a systematic review to summarize published results concerning the methods available for cannabis plant analysis over the period 2010-2016.

\section{Methods}


The systematic review produced was based on relevancy to the topics of cannabis plant analysis, profile of cannabis and methodology of cannabis analysis. The source used for guidance and to performe the present paper was the PRISMA guidelines (17).

\section{Search strategy}

A systematic literature search was carried out by consulting six electronic scientific databases: PubMed (MEDLINE), LILACS, Scopus, SciELO and Google Scholar, through July 2016 to August 2016.

A combination of the following search terms was used: "cannabis", "marijuana", "cannabinoids", phytocannabinoids", “drug detection", "analytical methods", "plant" and "herbal". The publication date was imposed as restriction to the retrieved articles: from 2010 through August 2016. Manuscripts were limited to English, Portuguese and Spanish languages.

\section{Selection criteria}

The follow inclusion criteria were established: 1) original research papers published since 2010 until August 2016; and 2) papers which evaluate analysis in cannabis plant material as the population of interest.

There were no limits for cannabis plants: preparations (herbal form - the leaves, flowering tops, and resin form - hashish, hash oil), chemotypes (fiber, intermediate or drug), phenotypes (genetic factors alleles $\mathrm{B}_{\mathrm{T}}, \mathrm{B}_{\mathrm{D}}, \mathrm{B}_{\mathrm{C}}$ and $\mathrm{B}_{0}$, a mutant form of the $\mathrm{B}_{\mathrm{D}}$ locus), varieties (indica, sativa or ruderalis), gender (male, female or monoecious), geographic location and origin, cultivation methods (outdoor, indoor, cloning or pollination), grown conditions (soil, humidity, temperature and photoperiod), growth period at harvesting, sample conservation at the time of analysis, or modes of supplying (seized, purchased or cultivated).

\section{Search articles}

The selection process concerning the articles to perform the paper (Figure 1) was accomplished uniformly by two independent researchers. Thus, both researchers conducted the screening, the determination of eligibility and the inclusion or exclusion of the papers related to methodology analysis for cannabis plant to attende this systematic review.

In the initial screening it was evaluated all titles and abstracts which researchers consider relevant. Articles that completely or partially lacked clear data to the information within the topic headings, such as analysis concerning synthetic cannabinoids or papers that showed solely the cannabis seizures data were rejected. The review papers and monographic scientific publications were also excluded of this study. There were no divergent opinions between the reviewers in including or excluding studies to eligible the articles for the systematic review.

\section{Data set}

After the selection performed at all databases involved in the study, repeated files were deleted and the remaining papers were placed in a single folder. The papers identified as potentially relevant were thoroughly reviewed and accepted or excluded from the study through consensus, by the reviewers.

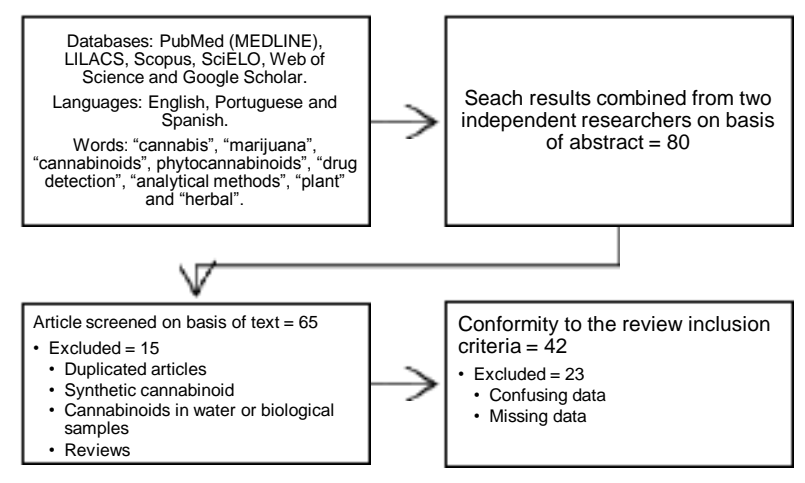

Figure 1 Selection process of the articles.

\section{Results and Discussion}

\section{Cannabis sativa L.: botanical aspects forensic view}

Although there is constant discussion regarding the botanical classification of cannabis (18-20) since it was first classified in 1753, by the Swedish botanist Carolus Linnaeus (Carl Von Linné), the "Recommended methods for the identification and analysis of cannabis and cannabis products" of the United Nations Office on Drugs and Crime considers that the plant has only one recognized specie, it is the Cannabis sativa L. (Linnaeus) $(9,18,19)$. Other species reported for the genus (C. sativa subsp. sativa, C. sativa subsp. indica, C. sativa subsp. ruderalis, $C$. sativa subsp. spontanea, C. sativa subsp. kafiristanca) currently are recognized as subspecies of the $C$. sativa L. $(9,18-20)$.

Furthermore, due to the difficulty of distinguishing the cannabis subspecies either in chemical terms or morphologically, given that cannabis presents continuous changes according to the environment and conditions in which it was planted, the designation $C$. sativa is considered suitable for all plants for the genus $(9,20)$.

Cannabis is an annual plant, dicotyledonous, angiosperm, usually dioecious, with male and female flowers on separate plants, but can also be monoecious, comprising flowers of both sexes in a single plant. The stamens (male) are generally higher, but less robust than the pistils (female). Before the occurrence of the flowering, the gender of the cannabis plant is 
indistinguishable, however, throughout the plant development each gender varies widely, and the difference among the male and female plant becomes evident. The roots are straight and can range from 0.2 to 6 meters, though the majority of plants reach heights from 1-3 meters. Both the branching degrees, such as plant height, depends on hereditary and environmental factors and the manner of cultivation $(9,21,22)$.

The fruits of cannabis, usually referred to as seeds, are small dried nuts, botanically named achene. The fruit contains one seed consists of two cotyledons and the major part of its mass is rich in reserve substances. The weight of achenes is quite variable, from 2 to 70 grams per 1,000 seeds. Typically, the seeds in monoecious varieties are smaller than in dioecious variety (21). The plant spreads from these seeds, which grow vigorously in sunny environments, with neutral to alkaline soils requiring nutrients and water in abundance. The pollen grains produced by male flowers require air currents to carry them to the female flowers, resulting in fertilization and consequent production of seeds $(9,21)$.

The cannabis growth cycle can be divided into four phases: germination and emergence; vegetative stage; flowering and seed formation; and senescence. The vegetative phase can be divided into three phases: juvenile stage; photosensitive phase; and flower development phase $(21,23)$. Male plants cease the dissemination after producing millions of pollens and then died $(9,21)$.

Because it is a short-day plant, the critical photoperiod of cannabis is the time of day which the seed is induced to flower in time when the juvenile stage be ready, corresponding to approximately 14 hours $(21,23)$. Flowering plant usually begins when the darkness exceeds 11 hours a day and this flowering cycle ranges between 4 and 12 weeks, depending on the strain and environmental conditions $(9,23)$. Shorter days (longest nights) induce early flowering and consequently the plant to complete its life cycle. Thus, cannabis starts flowering when exposed to short days 12 to 14 hours (nights from 10 to 12 hours or more). However, a single interrupted night of darkness can disrupt and delay the maturation of flowering. Moreover, maintain one or two short days may induce flowering, which may be irreversible in early maturing varieties (23).

After ripening seeds, they can be harvested, eaten by birds or rodents, or fall to the ground where they can germinate the following spring (9). The female plants produce several individual bunches of flowers, a large cluster on the upper torso and various small in each branch. Instead of setting the seeds in the first flowers, the female plants continue to produce additional flowers and these are covered by glands named trichomes containing a rich resin cannabinoids and terpenoids (22).

Although the genetics of the plant determines that it becomes male or female, environmental factors including the diurnal light cycle, can change the gender of the plant (hermaphrodites). Natural hermaphrodite with both genders are generally sterile, but induced hermaphrodites can artificially have fully functional reproductive organs. Feminized seeds of cannabis are obtained from artificially hermaphroditic females lacking the male chromosome or by seed treatment with hormones or silver thiosulphate. Thus, the production of pistils (female) can also be obtained by seeds $(9,21$, 23).

Over the years a wide variety of chemical constituents that are part of the various classes of natural products have been identified in C. sativa (24, 25). Currently, more than 750 chemical constituents have been identified in the plant (25). Among these, the natural products are mono- and sesquiterpenes, flavonoids, steroids, nitrogen compounds, besides the cannabinoids, the class of metabolites with toxicological significance $(24,25)$. Of the total compounds identified to date, more than 100 are classified as cannabinoids (25), which are encountered only in cannabis plants $(24,25)$.

The term "cannabinoids" refers to a group of $\mathrm{C}_{21}$ or $\mathrm{C}_{22}$ terpenophenolic compounds, including analogues and metabolites $(24,25)$. They are secondary metabolites with a predominantly nonpolar character and therefore poorly soluble in water. They are synthesized in secreting cells which are inside glandular trichomes $(26,27)$. These structures are present in greater proportion in the flowers and inflorescences (buds) female unfertilized prior to senescence $(26,28)$. Smaller amounts of cannabinoids are found in leaves, petioles and stems, and they are absent in the roots and seeds, since the seeds of cannabis are protected by bracts, forming structures called achenes. As a result, the latter plant organs do not contain cannabinoids (27, 28).

\section{Cannabis material analyzed}

According to UNODC (1), cannabis is opposite in relation to other drugs, because although the number of being stable seizures, the number of users and dependence reported increases each year $(1,29)$. It suggests that in 23 of the 50 north american states in which the medicinal and/or recreational use cannabis moves a business equivalent to the tobacco industry, being treated as a commodity (30). In the last two decades, the ratio of THC/CBD (cannabidiol) increased in the seized marijuana and this is linked to increase of neurotoxicity and cases of drug dependence (31). Functional neuroimaging studies have reported increases in neural activity in regions that may be related to cannabis intoxication or change in mood and reduction in activity of regions related to cognitive functions impaired during acute intoxication (32). Studies showed that frequent use is associated with greater severity of dependence, triplicates the chance of developing psychotic episodes and increased risk of cardiovascular disease and lung cancer (33-35). Therefore, the knowledge and understanding of 
cannabis and its compounds are very important to provide data for further researches and corroborate with the clinical findings about pontency of the drug. Furthermore, the results of analysis can provide similarities between samples, sources of interconnecting production and trafficking. So, the data set acquired from cannabis samples analysis may also provide informations which can trace ways to assist forensic experts and control the cannabis use.

Cannabis is a complex plant that naturally contains cannabinoids groups, closely related terpenophenolic compounds, which can occur a huge variation in their quantitative ratios. When study cannabis samples, understanding how the cannabinoids are chemically related to each other is substantial, since changes in the cannabinoid profile might occur not only in the different chemotypes. The conditions during growing and storage, such as environmental factors of cultivation (climates and elevation of cultivated area), the development stage of the plant at harvest time as well as genetic characteristics of seed-stocks are important factors that influence in the high variability and chemical composition of cannabinoids contents in cannabis plants $(6,36)$.

The progress in cannabis cultivation techniques have shown that stress conditions also increases the production of cannabinoids, besides have led to an increase in the potency and yield of cannabis. Advances including plantation using automated indoor lighting, ventilation, automated irrigation and fertilization and using selective breeding of certain strains of cannabis are some examples of the main techniques that have been used through of the last decade $(36,37)$.

Chemical types of cannabinoids can be divided in three groups: I) cannabinoids produced by biosynthesis of the plant (acid cannabinoids); II) cannabinoids present in the plant resulting from natural decarboxylation of acid cannabinoids (neutral cannabinoids) under the influence of storage, light and/or heat, by losing the relatively unstable carboxylgroup in the form of $\mathrm{CO}_{2}$; and III) cannabinoids occurring as artefacts by degradation products resulting from various influences, such as UV-light, oxidation or isomerization (38).

The most common types of acid cannabinoids found in cannabis plant are tetrahydrocannabinolic acid (THCA), cannabidiolic acid (CBDA), cannabigerolic acid (CBGA) and cannabichromenic acid (CBCA) (5, 6, 38). These acids can be converted to their neutral counterparts by decarboxylation to form $\Delta 9$ tetrahydrocannabinol $(\triangle 9-\mathrm{THC})$, cannabidiol (CBD), cannabigerol $(\mathrm{CBG})$ and cannabichromene (CBC), respectively $(6,11,36,38)$. Degradation of $\triangle 9$-THC results in formation of cannabinoids breakdown products as cannabinol $(\mathrm{CBN})$, produced by oxidative degradation (36-38) and $\Delta 8$-tetrahydrocannabinol $(\Delta 8$ THC) transformed by isomerization $(6,38)$, while THCA can further degrade into cannabinolic acid (CBNA) and this to $\mathrm{CBN}(5,38)$. The cannabinoids cannabicyclolic acid (CBLA) and cannabicyclol
(CBLA) arise, respectively, by exposure of CBCA and $\mathrm{CBC}$ to UV-radiation, leading to crosslinking of two double bonds in the molecule (38). Figure 2 shows the relationships between the main cannabinoid types that are usually detected in cannabis plant.

\section{Methods of analysis}

Although the most usual instrumental methods for analysis of cannabinoids are still GC/FID and LC/UV, and even the use of thin layer chromatography (TLC) is accepted as a confirmatory method for the cannabinoid profile by UNODC (9), the requirements for an acceptable cannabis assay and the knowledge of cannabinoids present in plant have changed dramatically over the years resulting in a large number of laboratories using a diverse array of analytical methodologies.

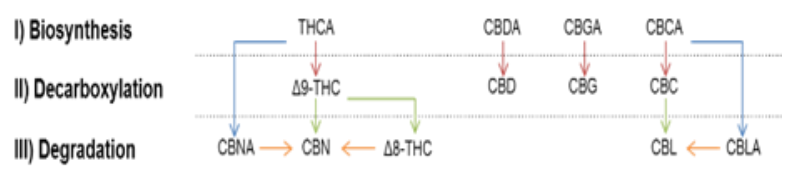

Figure 2 Relationships between the main cannabinoid types that are usually detected in cannabis plant as cannabinoids produced by biosynthesis, cannabinoids resulting from natural decarboxylation and cannabinoids as artefacts by degradation. CBC: cannabichromene; CBCA: cannabichromenic acid; CBD: cannabidiol; CBDA: cannabidiolic acid; CBG: cannabigerol; CBGA: cannabigerolic acid; CBL: cannabicyclol; CBLA: cannabicyclolic acid; CBN: cannabidiol; CBNA: cannabinolic acid; $\Delta 8$-THC: $\Delta 8$ tetrahydrocannabinol; $\quad \Delta 9$-THC: $\quad \Delta$ 9-tetrahydrocannabinol; THCA: tetrahydrocannabinolic acid.

\section{Gas Chromatography analysis}

GC is an appropriate method for cannabis profiles and chemical fingerprints, as it allows the identification of a large variety of cannabinoids with very high resolution, especially when coupled with MS (GC/MS). However, during the analysis the high temperatures required for sample vaporization before injection can result in decarboxylation of the acid cannabinoids to their corresponding neutral forms and the thermal degradation of some cannabinoids (13). Therefore, to quantifying cannabinoids by $\mathrm{GC}$ analysis is required to determine the total content of each cannabinoid (the sum of its acid and neutral form), because the thermal conversion of acid cannabinoids may be not complete, resulting in a nonrepresentative analysis of the cannabis samples $(6,13)$.

To avoid the decarboxylation of acid forms, a timeconsuming derivatization before GC analysis must be performed (39), e.g. by silylation as the trimethylsilyl ethers. However, an effective derivatization yield for all components in a complex mixture is difficult to achieve (13) and may also occur the thermo-degradation of 
derivatized cannabinoids in injector and/or column system (40). Whereas the cannabis plant mainly contains the acid forms of cannabinoids, GC analysis presents a limited value to establish the metabolic profile of a cannabinoid sample. Table 1 lists all the GC methods described in the articles included in this systematic review.

\section{Liquid Chromatography analysis}

An accurate manner to assay the cannabis composition is to use a method that does not involve thermal stress, such as LC (40). This technique allows the simultaneous detection of both acid and neutral cannabinoids with no need of derivatization. However, the complex composition of the cannabis material leads to an arduous perform to achieve the separation of major cannabinoids and significant peak overlap occurs. The use of LC coupled with MS (LC/MS) may assist to resolve cannabinoids of interest though LC/MS but does not allow characterization of an entire cannabis sample, merely the determination of specific analytes (13). Table 2 lists all the LC methods described in the articles included in this systematic review.

\section{Mass spectrometry detector and analysis}

MS is a technique that can be used as a detector, coupled to a chromatography system or the sample may be analyzed directly in MS, lacking the separation of compounds contained in the sample. The main MS objective, as a detector or a method of analysis is to identify an analyte, especially in the presence of other analytes, based on the measurement of the analyte ion mass, according to their different mass ratios/charge $(m / z)(41,42)$. Table 3 lists all the MS parameters used to identify cannabinoids, described in the articles included in this systematic review.

Although the full analysis of a complete cannabis extract with a single HPLC method is hard, resulting in chromatographic overlap, the HPLC method may be routinely combined with a secondary analysis by GC. Similarly, the difficulty to analyze both the acid cannabinoids and neutral with a GC method due to the necessity of derivatizing the acid forms, the GC method may also be combined with a secondary analysis by HPLC. By combining these two techniques of analysis, all major cannabinoids could be effectively identified and quantified.

Simultaneously to the methods presented in Table 1, Table 2 and Table 3, there are some additional techniques and approaches that can be applied to the analysis of cannabis products. Methods for the identification of marijuana include: botanical identification, microscopical examination of leaves (58), chemical screening tests (57-59), THC identification through biochemical methods (60), and the use of molecular sequencing to identify DNA sequence homology to reference marijuana samples (61-63). Besides that, there are some unusual techniques used for this proposital, such as Nuclear Magnetic Resonance and electronic nose systems $(51,54)$

The genetic analysis provides the opportunity to link products on the basis of their genetic profiles, which could be useful from an investigative point of view, e.g. to link producers, traffickers and consumers (9). The main technique used is the PCR for analysis of SNPs $(15,28)$, Inter-Simple Sequence Repeat (ISSR) $(49,61)$, STR $(45,62)$ or specific genes $(16,63)$. However, unlike humans, the DNA fingerprint may not necessarily be unique, as cloning of cannabis strains is quite common. Matching DNA profiles of two samples does not by itself prove that they come from the same plant, let alone the same grower (9). Moreover, the diferent subspecies, as all other environmental and nutritional parameters affect the genetic analysis (45), along with the fact that genetic analysis of cannabis samples is a relatively expensive technique and sometimes questionable (9). It is not recommended to only perform genetic testing for forensic purposes. 


\begin{tabular}{|c|c|c|c|c|c|c|}
\hline Reference & Extraction method & Solvent extraction & Column & GC conditions & Cannabinoids & Detector \\
\hline \multirow[b]{3}{*}{ (3) } & \multirow[b]{3}{*}{ liquid-liquid } & \multirow{3}{*}{$\begin{array}{l}\text { hexane / ethyl acetate } \\
\text { (6:4) }\end{array}$} & \multirow{3}{*}{$\begin{array}{l}\text { HP-5MS ( } 30 \mathrm{~m}, 0.25 \mathrm{~mm} \text { i.d., } 0.25 \mu \mathrm{m} \\
\text { film thickness) with a stationary phase } \\
\text { of } 5 \% \text { phenyl and } 95 \% \text { dimethyl } \\
\text { polysiloxane }\end{array}$} & \multirow{3}{*}{$\begin{array}{l}\text { Temperature program } \\
\text { starts at } 100{ }^{\circ} \mathrm{C} \text { (hold } \\
\text { for } 1 \mathrm{~min} \text { ), increases to } \\
290{ }^{\circ} \mathrm{C} \text { (at } 20^{\circ} \mathrm{C} / \mathrm{min} \text { ) } \\
\text { and holds for } 10 \mathrm{~min} \text {. }\end{array}$} & CBD & \multirow[b]{3}{*}{ MS } \\
\hline & & & & & CBN & \\
\hline & & & & & THC & \\
\hline \multirow{8}{*}{ (7) } & \multirow{8}{*}{ liquid-liquid } & \multirow{8}{*}{ hexane } & \multirow{8}{*}{$\begin{array}{l}\text { HP-5ms (30 m, } 0.25 \mathrm{~mm} \text { i.d., } 0.25 \mu \mathrm{m} \\
\text { film thickness) }\end{array}$} & \multirow{8}{*}{$\begin{array}{l}\text { Temperature program } \\
\text { starts at } 100{ }^{\circ} \mathrm{C}, \\
\text { increases to } 260^{\circ} \mathrm{C}(\text { at } \\
\left.10{ }^{\circ} \mathrm{C} / \mathrm{min}\right) \text { and holds } \\
\text { for } 10 \mathrm{~min}\end{array}$} & cannabinoid 1 & \multirow{8}{*}{ MS } \\
\hline & & & & & THV & \\
\hline & & & & & cannabinoid 2 & \\
\hline & & & & & CBL & \\
\hline & & & & & CBD & \\
\hline & & & & & THC & \\
\hline & & & & & CBG & \\
\hline & & & & & $\mathrm{CBN}$ & \\
\hline \multirow{5}{*}{ (8) } & \multirow{5}{*}{ liquid-liquid } & \multirow{5}{*}{ hexane } & \multirow{5}{*}{$\begin{array}{l}\text { HP-5MS ( } 30 \mathrm{~m}, 0.25 \mathrm{~mm} \text { i.d., } 0.25 \\
\mu \mathrm{m}), 5 \% \text { phenylmethylpolysiloxane }\end{array}$} & \multirow{5}{*}{$\begin{array}{l}\text { Temperature program } \\
\text { starts at } 100{ }^{\circ} \mathrm{C} \text { (hold } \\
\text { for } 1 \mathrm{~min} \text { ), increases to } \\
260{ }^{\circ} \mathrm{C} \text { (at } 10{ }^{\circ} \mathrm{C} \\
\mathrm{min} / \mathrm{min} \text { ) and holds for } \\
10 \mathrm{~min}\end{array}$} & $\mathrm{CBC}$ & \multirow{5}{*}{ MS } \\
\hline & & & & & CBD & \\
\hline & & & & & THC & \\
\hline & & & & & CBG & \\
\hline & & & & & $\mathrm{CBN}$ & \\
\hline \multirow{7}{*}{ (10) } & \multirow{7}{*}{ liquid-liquid } & \multirow{7}{*}{ methanol } & \multirow{7}{*}{$\begin{array}{c}\text { HP-5MS (30 m, } 0.25 \mathrm{~mm} \text { i.d., } 0.25 \mu \mathrm{m} \\
\text { film thickness })\end{array}$} & \multirow{7}{*}{$\begin{array}{l}\text { Temperature program } \\
\text { starts at } 150{ }^{\circ} \mathrm{C} \text { (hold } \\
\text { for } 1 \mathrm{~min} \text { ), increases to } \\
280{ }^{\circ} \mathrm{C} \text { (at } 10^{\circ} \mathrm{C} / \mathrm{min} \text { ) } \\
\text { and hold for } 5 \mathrm{~min}\end{array}$} & $\Delta 8-\mathrm{THC}$ & \multirow{7}{*}{ FID and MS } \\
\hline & & & & & THCV & \\
\hline & & & & & $\mathrm{CBC}$ & \\
\hline & & & & & CBD & \\
\hline & & & & & THC & \\
\hline & & & & & CBG & \\
\hline & & & & & $\mathrm{CBN}$ & \\
\hline \multirow{6}{*}{ (12) } & \multirow{6}{*}{ liquid-liquid } & \multirow{6}{*}{ hexane } & \multirow{6}{*}{$\begin{array}{c}\text { HP-5MS (30 m, } 0.25 \mathrm{~mm} \text { i.d., } 0.25 \mu \mathrm{m} \\
\text { film thickness) }\end{array}$} & \multirow{6}{*}{$\begin{array}{l}\text { Temperature program } \\
\text { starts at } 100{ }^{\circ} \mathrm{C}, \\
\text { increases to } 260{ }^{\circ} \mathrm{C} \text { (at } \\
10{ }^{\circ} \mathrm{C} / \mathrm{min} \text { ) and holds } \\
\text { for } 10 \mathrm{~min}\end{array}$} & $\mathrm{CBC}$ & \multirow{6}{*}{ MS } \\
\hline & & & & & cannabivarin & \\
\hline & & & & & CBD & \\
\hline & & & & & THC & \\
\hline & & & & & CBG & \\
\hline & & & & & $\mathrm{CBN}$ & \\
\hline
\end{tabular}




\begin{tabular}{|c|c|c|c|c|c|c|}
\hline \multirow{3}{*}{ (36) } & \multirow{3}{*}{ liquid-liquid } & \multirow{3}{*}{ methanol } & \multirow{3}{*}{$\begin{array}{l}\text { DB-1 (30 m, } 0.32 \mathrm{~mm} \text { i.d., } 0.25 \mu \mathrm{m} \\
\text { film thickness) }\end{array}$} & \multirow{3}{*}{$\begin{array}{l}\text { Temperature program } \\
\text { starts at } 230^{\circ} \mathrm{C} \text { (hold } \\
\text { for } 7 \mathrm{~min} \text { ), increases to } \\
260^{\circ} \mathrm{C} \text { (at } 10^{\circ} \mathrm{C} / \mathrm{min} \text { ) } \\
\text { and holds for } 2 \mathrm{~min}\end{array}$} & CBD & \multirow{3}{*}{ FID } \\
\hline & & & & & THC & \\
\hline & & & & & $\mathrm{CBN}$ & \\
\hline \multirow{3}{*}{ (37) } & \multirow{3}{*}{ liquid-liquid } & \multirow{3}{*}{$\begin{array}{l}0.5 \mathrm{mg} / \mathrm{mL} \\
\text { tribenzylamine in ethanol }\end{array}$} & \multirow{3}{*}{$\begin{array}{l}\text { HP } 1 \text { (25 m, } 0.32 \mathrm{~mm} \text { i.d., } 0.52 \mathrm{~mm} \\
\text { film thickness })\end{array}$} & \multirow{3}{*}{$\begin{array}{c}\text { Temperature program } \\
\text { starts at } 250{ }^{\circ} \mathrm{C} \text { (hold } \\
9.50 \mathrm{~min}) \\
\end{array}$} & THC & \multirow{3}{*}{ FID and MS } \\
\hline & & & & & CBD & \\
\hline & & & & & $\mathrm{CBN}$ & \\
\hline \multirow{6}{*}{ (43) } & \multirow{6}{*}{ liquid-liquid } & \multirow{6}{*}{$\begin{array}{c}100 \mathrm{mg} \text { of } 4 \text {-androstene- } \\
\text { 3,17-dione }+10 \mathrm{~mL} \\
\text { chloroform }+90 \mathrm{~mL} \\
\text { methanol }\end{array}$} & \multirow{6}{*}{$\begin{array}{c}\text { DB-1 (15 m, } 0.25 \mathrm{~mm} \text { i.d., } 0.25 \mu \mathrm{m} \\
\text { film) }\end{array}$} & \multirow{6}{*}{$\begin{array}{l}\text { Temperature program } \\
\text { starts at } 170^{\circ} \mathrm{C} \text { (hold } \\
\text { for } 1 \mathrm{~min} \text { ), increases to } \\
250{ }^{\circ} \mathrm{C} \text { (at } 10^{\circ} \mathrm{C} / \mathrm{min} \text { ) } \\
\text { and holds for } 3 \mathrm{~min}\end{array}$} & THC & \multirow{6}{*}{ FID } \\
\hline & & & & & THCV & \\
\hline & & & & & CBD & \\
\hline & & & & & $\mathrm{CBC}$ & \\
\hline & & & & & CBG & \\
\hline & & & & & $\mathrm{CBN}$ & \\
\hline \multirow{9}{*}{ (44) } & \multirow{9}{*}{ liquid-liquid } & \multirow{9}{*}{ ethanol } & \multirow{9}{*}{$\begin{array}{c}\text { DB5 (30 m, } 0.25 \mathrm{~mm} \text { i.d., } 0.25 \mu \mathrm{m} \text { film } \\
\text { thickness) }\end{array}$} & \multirow{9}{*}{$\begin{array}{l}\text { Temperature program } \\
\text { starts at } 60{ }^{\circ} \mathrm{C} \text {, } \\
\text { increases to } 240{ }^{\circ} \mathrm{C} \text { (at } \\
3{ }^{\circ} \mathrm{C} / \mathrm{min} \text { ) and holds } \\
\text { for } 5 \mathrm{~min}\end{array}$} & CBDV & \multirow{9}{*}{ FID } \\
\hline & & & & & THCV & \\
\hline & & & & & CBD & \\
\hline & & & & & $\mathrm{CBC}$ & \\
\hline & & & & & $\mathrm{CB}(1)$ & \\
\hline & & & & & CBGM & \\
\hline & & & & & $\Delta 8$-THC & \\
\hline & & & & & THC & \\
\hline & & & & & CBG & \\
\hline \multirow{9}{*}{ (44) } & \multirow{9}{*}{ liquid-liquid } & \multirow{9}{*}{ ethanol } & \multirow{9}{*}{$\begin{array}{c}\text { HP5 (30 m, } 0.25 \mathrm{~mm} \text { i.d., } 0.25 \mu \mathrm{m} \text { film } \\
\text { thickness) }\end{array}$} & \multirow{9}{*}{$\begin{array}{l}\text { Temperature program } \\
\text { starts at } 60{ }^{\circ} \mathrm{C} \text {, } \\
\text { increases to } 240{ }^{\circ} \mathrm{C} \text { (at } \\
3{ }^{\circ} \mathrm{C} / \mathrm{min} \text { ) and holds } \\
\text { for } 5 \text { min }\end{array}$} & CBDV & \multirow{9}{*}{ MS } \\
\hline & & & & & THCV & \\
\hline & & & & & CBD & \\
\hline & & & & & $\mathrm{CBC}$ & \\
\hline & & & & & $\mathrm{CB}(1)$ & \\
\hline & & & & & CBGM & \\
\hline & & & & & $\Delta 8$-THC & \\
\hline & & & & & THC & \\
\hline & & & & & CBG & \\
\hline
\end{tabular}


Drug Anal Res, 2017; 01, 1-23

\begin{tabular}{|c|c|c|c|c|c|c|}
\hline$(45)$ & liquid-liquid & ethanol & HP5ms (30 m) & $\begin{array}{l}\text { Temperature program } \\
\text { starts at } 80{ }^{\circ} \mathrm{C} \text { (hold } 1 \\
\text { min), increases to } 300 \\
{ }^{\circ} \mathrm{C} \text { (at } 50{ }^{\circ} \mathrm{C} / \mathrm{min} \text { ) and } \\
\text { holds for } 9.6 \mathrm{~min}\end{array}$ & THC & MS \\
\hline \multirow{6}{*}{ (46) } & \multirow{6}{*}{-} & \multirow{6}{*}{-} & \multirow{6}{*}{$\begin{array}{c}\text { DB-1 (15 m, } 0.25 \mathrm{~mm} \text { i.d., } 0.25 \mu \mathrm{m} \\
\text { film) }\end{array}$} & \multirow{6}{*}{$\begin{array}{l}\text { Temperature program } \\
\text { starts at } 170{ }^{\circ} \mathrm{C} \text { (hold } \\
\text { for } 1 \mathrm{~min} \text { ), increases to } \\
250^{\circ} \mathrm{C} \text { (at } 10^{\circ} \mathrm{C} / \mathrm{min} \text { ) }\end{array}$} & THCV & \multirow{6}{*}{ FID } \\
\hline & & & & & CBD & \\
\hline & & & & & $\mathrm{CBC}$ & \\
\hline & & & & & THC & \\
\hline & & & & & CBG & \\
\hline & & & & & CBN & \\
\hline \multirow{6}{*}{ (47) } & \multirow{6}{*}{ liquid-liquid } & \multirow{6}{*}{$\begin{array}{c}100 \mathrm{mg} \text { of } 4 \text {-androstene- } \\
\text { 3,17-dione }+10 \mathrm{~mL} \\
\text { chloroform }+90 \mathrm{~mL} \\
\text { methanol }\end{array}$} & \multirow{6}{*}{$\begin{array}{c}\text { DB-1MS (15 m, } 0.25 \mathrm{~mm} \text { i.d., } 0.25 \mu \mathrm{m} \\
\text { film) }\end{array}$} & \multirow{6}{*}{$\begin{array}{l}\text { Temperature program } \\
\text { starts at } 170^{\circ} \mathrm{C} \text { (hold } \\
\text { for } 1 \mathrm{~min} \text { ), increases to } \\
250^{\circ} \mathrm{C} \text { (at } 10^{\circ} \mathrm{C} / \mathrm{min} \text { ) } \\
\text { and hold for } 3 \mathrm{~min}\end{array}$} & THC & \multirow{6}{*}{ FID } \\
\hline & & & & & THCV & \\
\hline & & & & & $\mathrm{CBC}$ & \\
\hline & & & & & CBD & \\
\hline & & & & & CBG & \\
\hline & & & & & $\mathrm{CBN}$ & \\
\hline \multirow{8}{*}{ (48) } & \multirow{8}{*}{ liquid-liquid } & \multirow{8}{*}{ ethanol } & \multirow{8}{*}{$\begin{array}{c}\text { DB5 (30 m, } 0.25 \mathrm{~mm} \text { i.d., } 0.25 \mu \mathrm{m} \text { film } \\
\text { thickness })\end{array}$} & \multirow{8}{*}{$\begin{array}{l}\text { Temperature program } \\
\text { starts at } 60^{\circ} \mathrm{C} \text {, } \\
\text { increases to } 240^{\circ} \mathrm{C} \text { (at } \\
3^{\circ} \mathrm{C} / \mathrm{min} \text { ) and holds } \\
\text { for } 5 \mathrm{~min}\end{array}$} & THCV & \multirow{8}{*}{ FID } \\
\hline & & & & & CBD & \\
\hline & & & & & $\mathrm{CBC}$ & \\
\hline & & & & & unknown cannabinoid & \\
\hline & & & & & CBGM & \\
\hline & & & & & THC & \\
\hline & & & & & CBG & \\
\hline & & & & & CBN & \\
\hline \multirow{8}{*}{$(48)$} & \multirow{8}{*}{ liquid-liquid } & \multirow{8}{*}{ ethanol } & \multirow{8}{*}{$\begin{array}{c}\text { HP5 (30 m, } 0.25 \mathrm{~mm} \text { i.d., } 0.25 \mu \mathrm{m} \text { film } \\
\text { thickness) }\end{array}$} & \multirow{8}{*}{$\begin{array}{l}\text { Temperature program } \\
\text { starts at } 60^{\circ} \mathrm{C} \text {, } \\
\text { increases to } 240^{\circ} \mathrm{C} \text { (at } \\
3{ }^{\circ} \mathrm{C} / \mathrm{min} \text { ) and holds } \\
\text { for } 5 \mathrm{~min}\end{array}$} & THCV & \multirow{8}{*}{ MS } \\
\hline & & & & & CBD & \\
\hline & & & & & $\mathrm{CBC}$ & \\
\hline & & & & & unknown cannabinoid & \\
\hline & & & & & CBGM & \\
\hline & & & & & THC & \\
\hline & & & & & CBG & \\
\hline & & & & & $\mathrm{CBN}$ & \\
\hline
\end{tabular}

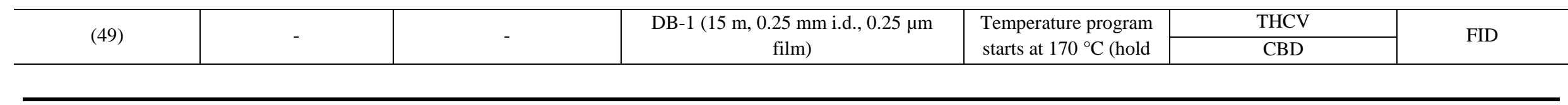




\begin{tabular}{|c|c|c|c|c|c|c|}
\hline & & & & for $1 \mathrm{~min}$ ), increases to & $\mathrm{CBC}$ & \\
\hline & & & & $250{ }^{\circ} \mathrm{C}$ (at $\left.10^{\circ} \mathrm{C} / \mathrm{min}\right)$ & THC & \\
\hline & & & & & CBN & \\
\hline \multirow{3}{*}{ (50) } & \multirow{3}{*}{ liquid-liquid } & \multirow{3}{*}{ methanol } & \multirow{3}{*}{$\begin{array}{l}\text { DB-1 (30 m, } 0.32 \mathrm{~mm} \text { i.d., } 0.25 \mu \mathrm{m} \\
\text { film thickness) }\end{array}$} & \multirow{3}{*}{$\begin{array}{l}\text { Temperature program } \\
\text { starts at } 230^{\circ} \mathrm{C} \text { (hold } \\
\text { for } 7 \mathrm{~min} \text { ), increases to } \\
260^{\circ} \mathrm{C} \text { (at } 10^{\circ} \mathrm{C} / \mathrm{min} \text { ) } \\
\text { and holds for } 2 \mathrm{~min}\end{array}$} & CBD & \multirow{3}{*}{ FID } \\
\hline & & & & & THC & \\
\hline & & & & & $\mathrm{CBN}$ & \\
\hline
\end{tabular}

CB(1): unknown cannabinoid; CBC: cannabichromene; CBD: cannabidiol; CBDV: cannabidivarin; CBG: cannabigerol; CBGM: cannabigerol monomethyl ether; CBL: cannabicyclol; CBN: cannabidiol; $\triangle 8$-THC: $\triangle 8$-tetrahydrocannabinol; THC: tetrahydrocannabinol; THCV: tetrahydrocannabivarin; FID: flame ionization detector; MS: mass spectrometry; 
Table 2 LC methods described in the articles included in this systematic review.

\begin{tabular}{|c|c|c|c|c|c|c|c|}
\hline Reference & $\begin{array}{l}\text { Extraction } \\
\text { method }\end{array}$ & $\begin{array}{c}\text { Solvent } \\
\text { extraction }\end{array}$ & Column & Mobile phase & $\begin{array}{c}\text { Flow } \\
(\mathrm{mL} / \mathrm{min})\end{array}$ & Cannabinoids & Detector \\
\hline \multirow{9}{*}{ (4) } & \multirow{9}{*}{ liquid-liquid } & \multirow{9}{*}{$\begin{array}{c}\text { methanol / } \\
\text { chloroform (9:1) }\end{array}$} & \multirow{9}{*}{$\begin{array}{l}\mathrm{C} 18(3.5 \mu \mathrm{m}, 150 \\
\mathrm{mm} \times 4.6 \mathrm{~mm} \text { i.d. }) \text { with a } \\
1 \mathrm{~mm} \text { opti-guard } \mathrm{C} 18 \\
\text { precolumn }\end{array}$} & \multirow{9}{*}{$\begin{array}{l}\text { solvent } \mathrm{A} \text { : } 50 \mathrm{mM} \text { ammonium formate buffer } \mathrm{pH} 3.75 \\
\text { with } 10 \% \text { acetonitrile, } \\
\text { solvent B: } 90 \% \text { acetronitrile; The gradient program: } 0 \\
\text { min, } 70 \% \text { B; } 15 \text { min, } 90 \% \text { B; } 30 \text { min, } 90 \% \text { B; } 31 \text { min, } \\
70 \% \text { B and } 40 \text { min } 70 \% .\end{array}$} & \multirow{9}{*}{1.0} & CBDA & \multirow{9}{*}{$\begin{array}{c}\text { DAD } \\
(272 \mathrm{~nm})\end{array}$} \\
\hline & & & & & & CBGA & \\
\hline & & & & & & CBG & \\
\hline & & & & & & $\mathrm{CBD}$ & \\
\hline & & & & & & THCV & \\
\hline & & & & & & $\mathrm{CBN}$ & \\
\hline & & & & & & THCA & \\
\hline & & & & & & THC & \\
\hline & & & & & & $\mathrm{CBC}$ & \\
\hline \multirow{8}{*}{ (5) } & \multirow{8}{*}{ liquid-liquid } & \multirow{8}{*}{$\begin{array}{c}\text { ethanol / } \\
\text { chloroform (9:1) }\end{array}$} & \multirow{8}{*}{$\begin{array}{l}\mathrm{C} 8(3 \mu \mathrm{m}, 125 \mathrm{~mm} \times 4 \\
\text { mm i.d. }) \text { with a guard } \\
\text { column }(3 \mu \mathrm{m} \text { depth } \\
\quad \text { filter } \times 4 \mathrm{~mm})\end{array}$} & \multirow{8}{*}{$\begin{array}{c}\text { solvent A: methanol and solvent B: water with } 0.1 \% \text { of } \\
\text { acid acetic). The gradient program: } 50 \% \text { A, increased } \\
\text { to } 90 \% \text { A over } 20 \text { min, maintained at } 90 \% \text { A over the } \\
\text { next } 1.5 \text { min, decreased to } 50 \% \text { A over the next } 0.5 \\
\text { min, and held at } 50 \%\end{array}$} & \multirow{8}{*}{0.7} & CBGA & \multirow{8}{*}{$\begin{array}{c}\text { DAD } \\
(230 \mathrm{~nm})\end{array}$} \\
\hline & & & & & & THCA & \\
\hline & & & & & & CBDA & \\
\hline & & & & & & CBG & \\
\hline & & & & & & THC & \\
\hline & & & & & & CBD & \\
\hline & & & & & & $\mathrm{CBC}$ & \\
\hline & & & & & & CBN & \\
\hline \multirow{8}{*}{ (6) } & \multirow{8}{*}{ liquid-liquid } & \multirow{8}{*}{$\begin{array}{c}\text { methanol / } \\
\text { chloroform (9:1) }\end{array}$} & \multirow{8}{*}{$\begin{array}{l}\mathrm{C} 18(5 \mu \mathrm{m}, 250 \times 2.1 \\
\text { mm i.d.) protected by a } \\
\mathrm{C} 18 \text { guard column }(5 \\
\mu \mathrm{m}, 10 \times 2.1 \mathrm{~mm} \text { i.d. })\end{array}$} & \multirow{8}{*}{$\begin{array}{l}\text { methanol / water } 50 \mathrm{mM} \text { of ammonium formate }(\mathrm{pH} \\
\text { 5.19). The gradient program: } 68 \% \text { methanol, increased } \\
\text { to } 90.5 \% \text { methanol over } 25 \mathrm{~min} \text {, then increased to } 95 \% \\
\text { in } 1 \mathrm{~min} \text { and maintaining for } 3 \mathrm{~min}\end{array}$} & \multirow{8}{*}{0.3} & CBDA & \multirow{4}{*}{$\begin{array}{l}\text { DAD } \\
(211 \mathrm{~nm}) \\
\text { neutral }\end{array}$} \\
\hline & & & & & & CBGA & \\
\hline & & & & & & CBD & \\
\hline & & & & & & CBG & \\
\hline & & & & & & THCA & \multirow{4}{*}{$\begin{array}{l}\text { DAD } \\
(220 \mathrm{~nm}) \\
\text { acids }\end{array}$} \\
\hline & & & & & & $\mathrm{CBN}$ & \\
\hline & & & & & & THC & \\
\hline & & & & & & $\Delta 8$-THC & \\
\hline \multirow{2}{*}{ (11) } & \multirow{2}{*}{ liquid-liquid } & \multirow{2}{*}{$\begin{array}{l}\text { hexane / ethyl } \\
\text { acetate (9:1) }\end{array}$} & \multirow{2}{*}{$\begin{array}{l}100 \mathrm{RP}-18(5 \mu \mathrm{m}) \\
\text { LiChroCart } 125-4\end{array}$} & \multirow{2}{*}{$\begin{array}{l}\text { Triethylammoniumphosphate buffer } \mathrm{pH} 3.0(25 \\
\mathrm{mmol} / \mathrm{L} \text { in nanopure water) and acetonitrile: } 36: 64, \text { in } \\
\text { isocratic mode }\end{array}$} & \multirow{2}{*}{1.5} & THC & \multirow{2}{*}{$\begin{array}{c}\text { UV } \\
(210 \mathrm{~nm})\end{array}$} \\
\hline & & & & & & THCA & \\
\hline
\end{tabular}




\begin{tabular}{|c|c|c|c|c|c|c|c|}
\hline \multirow{16}{*}{ (13) } & \multirow{16}{*}{$\begin{array}{r}\text { liquid-liquid } \\
\text { with soxhlet }\end{array}$} & \multirow{16}{*}{ ethyl acetate } & \multirow{4}{*}{$\begin{array}{l}\mathrm{CN} 100 \AA \text { ( } 4.60 \\
\mathrm{~mm} \times 150 \mathrm{~mm} \text { i.d., } 5 \\
\mu \mathrm{m})\end{array}$} & \multirow{4}{*}{$\begin{array}{c}\text { methanol and acid potassium permanganate } \\
\text { chemiluminescence; } 10 \% \text { methanol in the initial } \\
\text { mobile phase composition. The gradient program: } 0 \text { to } \\
70 \% \text { methanol over a gradient of } 12 \text { min followed by } 3 \\
\text { min of } 100 \% \text { metanol }\end{array}$} & \multirow{8}{*}{1.0} & $\mathrm{CBV}$ & \multirow{16}{*}{$\begin{array}{l}\text { 2D-HPLC: } \\
\text { UV (220 nm) } \\
\quad / \mathrm{CL}\end{array}$} \\
\hline & & & & & & $\mathrm{CBCV}$ & \\
\hline & & & & & & CBDV & \\
\hline & & & & & & CBLV & \\
\hline & & & \multirow{4}{*}{$\begin{array}{l}\mathrm{EC}-\mathrm{C} 18(4.60 \mathrm{~mm} \times 50 \\
\mathrm{mm} \text { i.d., } 2.7 \mu \mathrm{m})\end{array}$} & \multirow{4}{*}{$\begin{array}{l}\text { methanol and acid potassium permanganate } \\
\text { chemiluminescence; The gradient program: } 0 \text { to } 100 \% \\
\text { methanol in } 3 \text { min followed by } 3 \text { min of } 100 \% \text { metanol }\end{array}$} & & CBGV & \\
\hline & & & & & & CBN & \\
\hline & & & & & & CBD & \\
\hline & & & & & & CBL & \\
\hline & & & \multirow{8}{*}{ - } & \multirow{8}{*}{$\begin{array}{l}\text { Postcolumn acid potassium permanganate } \\
\text { chemiluminescence was generated using custom-built } \\
\text { manifold. The chemiluminescence reagent merged with } \\
\text { the HPLC eluent at a T-piece junction and the light } \\
\text { emitted from the reacting mixture was detected. }\end{array}$} & \multirow{8}{*}{1.2} & CBG & \\
\hline & & & & & & $\mathrm{CBE}$ & \\
\hline & & & & & & CBT & \\
\hline & & & & & & CBNA & \\
\hline & & & & & & CBCA & \\
\hline & & & & & & CBDA & \\
\hline & & & & & & CBLA & \\
\hline & & & & & & CBGA & \\
\hline \multirow{4}{*}{$(14)$} & \multirow{4}{*}{ liquid-liquid } & \multirow{4}{*}{$\begin{array}{l}\text { methanol / } \mathrm{n}- \\
\text { hexane }(9: 1)\end{array}$} & \multirow{4}{*}{$\begin{array}{l}\text { LiChroCart 125-4, } \\
\text { LiChrospher 60, RP- } \\
\text { Select B, } 5 \mu \mathrm{m} \text {, column } \\
\text { holder: manu-CART } \\
\text { "4" and pre column: } \\
\text { LiChrospher 60, RP- } \\
\text { Select B, } 5 \mu \mathrm{m} \text {, }\end{array}$} & \multirow{4}{*}{$\begin{array}{l}\text { TEAP buffer } 25 \mathrm{mmol} / \mathrm{L} \text { in deionized water and } \\
\text { acetonitrile: } 36: 64 \text {, in isocratic mode }\end{array}$} & \multirow{4}{*}{1.0} & $\mathrm{CBD}$ & \multirow{4}{*}{$\begin{array}{l}\text { DAD } \\
(210 \mathrm{~nm})\end{array}$} \\
\hline & & & & & & $\mathrm{CBN}$ & \\
\hline & & & & & & THC & \\
\hline & & & & & & THCA & \\
\hline \multirow{3}{*}{ (39) } & \multirow{3}{*}{ liquid-liquid } & \multirow{3}{*}{$\begin{array}{c}\text { methanol / } \\
\text { chloroform (9:1) }\end{array}$} & \multirow{3}{*}{$\begin{array}{l}\text { Onyx Monolithic (100 } \\
\mathrm{mm} \times 4.6 \mathrm{~mm} \text { i.d.) }\end{array}$} & \multirow{3}{*}{ methanol and water: $75: 25$, in isocratic mode } & \multirow{3}{*}{0.8} & CBD & \multirow{3}{*}{$\begin{array}{c}\text { PDA } \\
(220 \mathrm{~nm})\end{array}$} \\
\hline & & & & & & $\mathrm{CBN}$ & \\
\hline & & & & & & THC & \\
\hline
\end{tabular}




\begin{tabular}{|c|c|c|c|c|c|c|c|}
\hline \multirow{13}{*}{ (40) } & \multirow{13}{*}{ HTH } & \multirow{13}{*}{ ethanol } & \multirow{13}{*}{$\begin{array}{l}\text { EC-C18 }(150 \mathrm{~mm} \times 2.1 \\
\text { mm i.d., } 2.7 \mu \mathrm{m}) \text { with a } \\
\text { EC-C18 guard column } \\
(5 \times 2.1 \mathrm{~mm} \text { i.d., } 2.7 \mu \mathrm{m})\end{array}$} & \multirow{13}{*}{$\begin{array}{l}\text { solvent A: water, } 0.1 \% \text { formic acid and solvent } \mathrm{B} \text { : } \\
0.1 \% \text { formic acid. The gradient program: } 8 \mathrm{~min} \\
\text { isocratic hold at } 66 \% \mathrm{~B} \text {, gradient to } 95 \% \mathrm{~B} \\
\text { over } 4 \mathrm{~min} ; 95 \% \mathrm{~B} \text { maintained for } 1 \mathrm{~min}\end{array}$} & \multirow{13}{*}{0.5} & CBDVA & \multirow{13}{*}{$\begin{array}{c}\text { DAD } \\
(200-400 \\
\text { and } 214 \mathrm{~nm})\end{array}$} \\
\hline & & & & & & CBDV & \\
\hline & & & & & & CBDA & \\
\hline & & & & & & CBGA & \\
\hline & & & & & & CBG & \\
\hline & & & & & & CBD & \\
\hline & & & & & & THCV & \\
\hline & & & & & & THCVA & \\
\hline & & & & & & CBN & \\
\hline & & & & & & THC & \\
\hline & & & & & & $\Delta 8-\mathrm{THC}$ & \\
\hline & & & & & & $\mathrm{CBC}$ & \\
\hline & & & & & & THCA & \\
\hline \multirow{9}{*}{$(51)$} & \multirow{9}{*}{ liquid-liquid } & \multirow{9}{*}{ methanol } & \multirow{9}{*}{$\begin{array}{l}\mathrm{C} 18(5 \mu \mathrm{m}, 150 \\
\mathrm{mm} \times 2.1 \mathrm{~mm} \text { i.d. })\end{array}$} & \multirow{9}{*}{$\begin{array}{c}\text { solvent A: water, } 0.1 \% \text { formic acid and solvent B: } \\
\text { methanol, } 0.1 \% \text { formic acid. The gradient program: } \\
\text { 30\% B, increased to } 70 \% \text { B in } 1 \text { min, then increased to } \\
90 \% \text { B in } 30 \mathrm{~min}\end{array}$} & \multirow{9}{*}{0.25} & THCA-D3 & \multirow{9}{*}{ MS } \\
\hline & & & & & & CBD & \\
\hline & & & & & & CBG & \\
\hline & & & & & & CBDA & \\
\hline & & & & & & CBN & \\
\hline & & & & & & THC & \\
\hline & & & & & & $\Delta 8-\mathrm{THC}$ & \\
\hline & & & & & & CBC & \\
\hline & & & & & & THCA & \\
\hline$(52)$ & CPE & $\begin{array}{c}0.1 \text { to } 0.7 \mathrm{~g} \\
\text { Dowfax } 20 \mathrm{~B} 102 \\
+0.2 \mathrm{~g} \mathrm{Na}_{2} \mathrm{SO}_{4} \\
\text { diluted to } 10 \mathrm{~mL} \\
\text { with deionized } \\
\text { water }\end{array}$ & $\begin{array}{c}\mathrm{C} 18(5 \mu \mathrm{m}, 250 \times 4.6 \\
\mathrm{mm} \text { i.d. })\end{array}$ & $\begin{array}{l}\text { Acetonitrile and water, acidified with } 2.5 \mathrm{M} \mathrm{H}_{2} \mathrm{SO}_{4} \\
\qquad(\mathrm{pH}=1.8): 83: 17 \text {, in isocratic mode }\end{array}$ & 1.0 & THC & $\begin{array}{l}\text { UV (DAD) } \\
(231 \mathrm{~nm})\end{array}$ \\
\hline
\end{tabular}




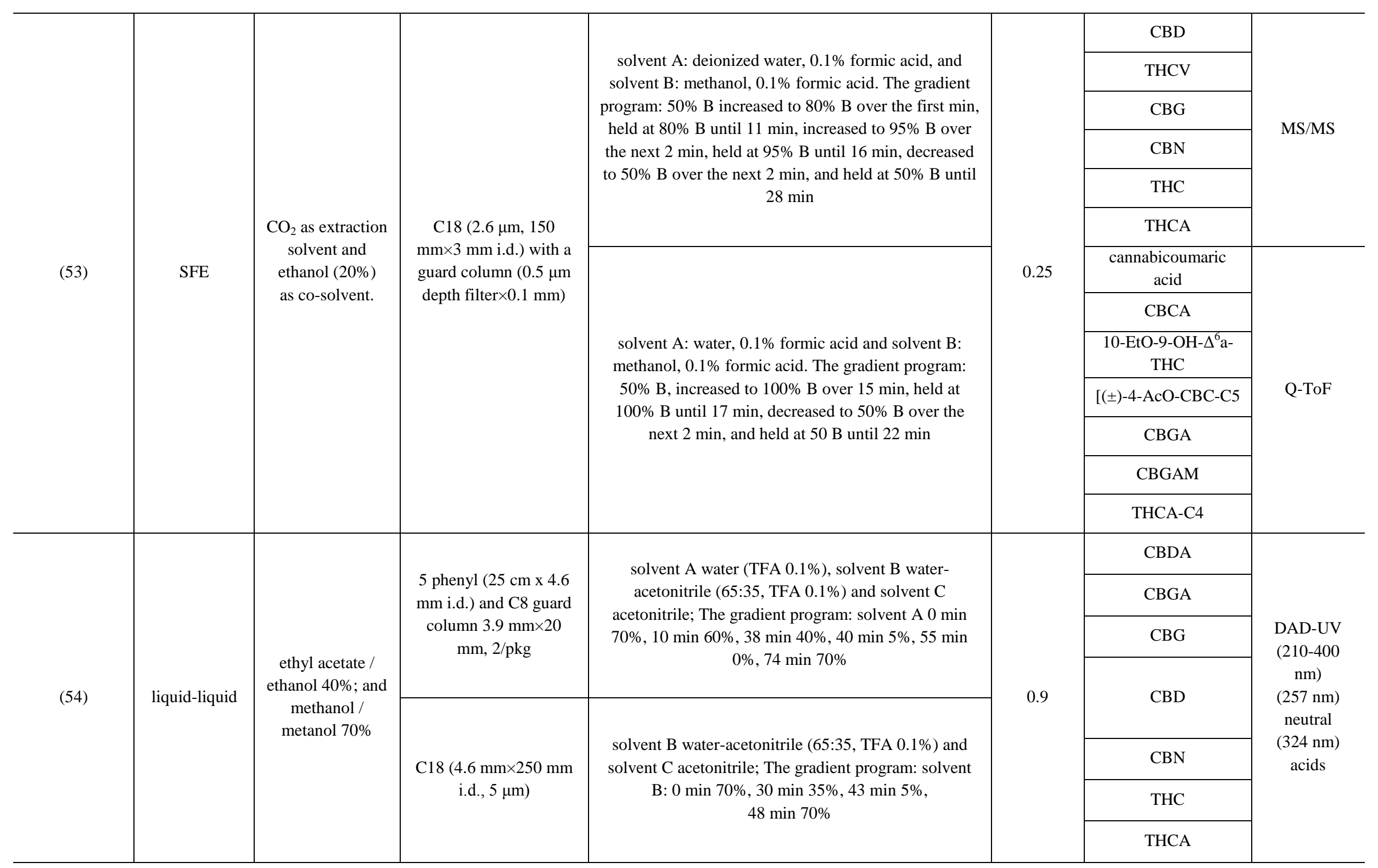




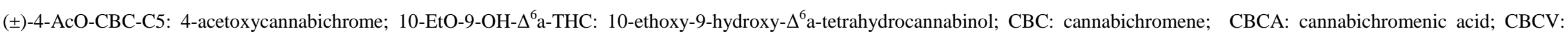
cannabichromevarin; CBD: cannabidiol; CBDA: cannabidiolic acid; CBDV: cannabidivarin; CBDVA: cannabidivarinic acid; CBE: cannabielsoin; CBG: cannabigerol; CBGA: cannabigerolic acid; CBGAM: cannabigerolic acid A monomethyl ether; CBGV: cannabigerovarin; CBL: cannabicyclol; CBLA: cannabicyclolic acid; CBLV: cannabicyclolvarin; CBN: cannabidiol; CBNA: cannabinolic acid; CBT: cannabicitran; CBV: cannabivarin; CL: chemiluminescence; CPE: cloud point extraction; DAD: diode-array detector; $\triangle 8$-THC: $\triangle 8$-tetrahydrocannabinol; HTH: high throughput homogenization; MS/MS: tandem mass spectrometry; THC: tetrahydrocannabinol; THCA: tetrahydrocannabinolic acid; THCA-C4: tetrahydrocannabinolic acid-C4; THCA-D3: ( \pm -11-nor- $\triangle$ 9-THC carboxylic acid-D3; THCV: tetrahydrocannabivarin; THCVA: tetrahydrocannabivarinic acid; PDA: photodiode-array detector; Q-ToF: quadrupole-time-of-flight; SFE: supercritical fluid extraction; TEAP: triethylammoniumphosphate $1 \mathrm{M}$; TOF: time-of-flight; UV: ultraviolet. 
Table 3 MS detector parameters used to identify cannabinoids, described in the articles included in this systematic review.

\begin{tabular}{|c|c|c|c|c|c|c|c|}
\hline Reference & Detector & Ionization mode & Cannabinoid & $\begin{array}{c}\text { Quantifier } \\
\text { ion }(m / z)\end{array}$ & $\begin{array}{l}\text { Qualifier ions } \\
\qquad(m / z)\end{array}$ & $\begin{array}{c}\text { Limit of } \\
\text { quantification } \\
\text { (LOQ) } \\
\end{array}$ & $\begin{array}{c}\text { Limit of } \\
\text { detection } \\
\text { (LOD) }\end{array}$ \\
\hline \multirow{3}{*}{ (3) } & \multirow{3}{*}{ MS } & \multirow{3}{*}{$\mathrm{EI}(70 \mathrm{~V})$} & CBD & 231 & 174,314 & $0.01 \%(\mathrm{w} / \mathrm{w})$ & $0.005 \%(\mathrm{w} / \mathrm{w})$ \\
\hline & & & $\mathrm{CBN}$ & 295 & 238,310 & $0.01 \%(\mathrm{w} / \mathrm{w})$ & $0.005 \%(\mathrm{w} / \mathrm{w})$ \\
\hline & & & THC & 299 & 314,231 & $0.01 \%(\mathrm{w} / \mathrm{w})$ & $0.005 \%(\mathrm{w} / \mathrm{w})$ \\
\hline \multirow{8}{*}{ (7) } & \multirow{8}{*}{ MS } & \multirow{8}{*}{$\begin{array}{c}\text { electron multiplier voltage } \\
(1976 \mathrm{~V}) \text {, ion source }\left(230^{\circ} \mathrm{C}\right), \\
\text { quadrupole }\left(150^{\circ} \mathrm{C}\right)\end{array}$} & cannabinoid 1 & 231 & $314,299,271$ & \multirow{8}{*}{-} & \multirow{8}{*}{-} \\
\hline & & & THV & 271 & $286,203,243$ & & \\
\hline & & & cannabinoid 2 & 231 & $314,174,243$ & & \\
\hline & & & $\mathrm{CBL}$ & 231 & $232,274,314$ & & \\
\hline & & & CBD & 231 & $174,314,299$ & & \\
\hline & & & THC & 299 & $314,231,271$ & & \\
\hline & & & CBG & 193 & $231,123,316$ & & \\
\hline & & & $\mathrm{CBN}$ & 295 & $238,310,223$ & & \\
\hline \multirow{5}{*}{ (8) } & \multirow{5}{*}{ MS } & \multirow{5}{*}{-} & $\mathrm{CBC}$ & \multirow{5}{*}{-} & \multirow{5}{*}{-} & \multirow{5}{*}{-} & \multirow{5}{*}{-} \\
\hline & & & CBD & & & & \\
\hline & & & THC & & & & \\
\hline & & & CBG & & & & \\
\hline & & & $\mathrm{CBN}$ & & & & \\
\hline \multirow{7}{*}{ (10) } & \multirow{7}{*}{ MS } & \multirow{7}{*}{$\mathrm{EI}(70 \mathrm{~V})$} & $\Delta 8$-THC & \multirow{7}{*}{-} & \multirow{7}{*}{-} & \multirow{7}{*}{-} & \multirow{7}{*}{ - } \\
\hline & & & THCV & & & & \\
\hline & & & $\mathrm{CBC}$ & & & & \\
\hline & & & CBD & & & & \\
\hline & & & THC & & & & \\
\hline & & & CBG & & & & \\
\hline & & & CBN & & & & \\
\hline \multirow{6}{*}{ (12) } & \multirow{6}{*}{ MS } & \multirow{6}{*}{$\begin{array}{c}\text { electron multiplier voltage } \\
(1200 \mathrm{~V}) \text {, ion source }\left(230^{\circ} \mathrm{C}\right), \\
\text { quadrupole }\left(150^{\circ} \mathrm{C}\right)\end{array}$} & $\mathrm{CBC}$ & 231 & $174,314,299$ & \multirow{6}{*}{ - } & \multirow{6}{*}{-} \\
\hline & & & cannabivarin & 267 & $282,238,223$ & & \\
\hline & & & CBD & 231 & $174,314,246$ & & \\
\hline & & & THC & 299 & $314,231,271$ & & \\
\hline & & & CBG & 93 & $231,123,316$ & & \\
\hline & & & $\mathrm{CBN}$ & 295 & $238,310,223$ & & \\
\hline
\end{tabular}




\begin{tabular}{|c|c|c|c|c|c|c|c|}
\hline \multirow{17}{*}{ (13) } & \multirow{17}{*}{ TOF } & \multirow{17}{*}{$\begin{array}{l}\text { ESI positive mode, nitrogen (as } \\
\left.\text { drying gas: } 7 \mathrm{~mL} / \mathrm{min}, 350{ }^{\circ} \mathrm{C}\right) \\
\text { and (as nebulizer gas: } 16 \mathrm{psi}) \text {, } \\
\text { capillary voltage }(4.0 \mathrm{kV}), \\
\text { vaporizer temperature }(350 \\
\left.{ }^{\circ} \mathrm{C}\right) \text {, cone voltage }(60 \mathrm{~V})\end{array}$} & $\mathrm{CBV}$ & \multirow{17}{*}{-} & 282.38 & \multirow{17}{*}{-} & \multirow{17}{*}{ - } \\
\hline & & & $\mathrm{CBCV}$ & & 286.41 & & \\
\hline & & & CBDV & & 286.41 & & \\
\hline & & & CBLV & & 286.41 & & \\
\hline & & & CBGV & & 288.42 & & \\
\hline & & & $\mathrm{CBN}$ & & 310.43 & & \\
\hline & & & $\mathrm{CBC}$ & & 314.46 & & \\
\hline & & & CBD & & 314.46 & & \\
\hline & & & CBL & & 314.46 & & \\
\hline & & & $\overline{\mathrm{CBG}}$ & & 316.48 & & \\
\hline & & & $\mathrm{CBE}$ & & 330.46 & & \\
\hline & & & CBT & & 346.46 & & \\
\hline & & & CBNA & & 354.44 & & \\
\hline & & & CBCA & & 358.47 & & \\
\hline & & & CBDA & & 358.47 & & \\
\hline & & & CBLA & & 358.47 & & \\
\hline & & & CBGA & & 360.49 & & \\
\hline \multirow{3}{*}{ (37) } & \multirow{3}{*}{ MS } & \multirow{3}{*}{ - } & THC & \multirow{3}{*}{-} & \multirow{3}{*}{-} & \multirow{3}{*}{-} & \multirow{3}{*}{ - } \\
\hline & & & CBD & & & & \\
\hline & & & $\mathrm{CBN}$ & & & & \\
\hline (45) & MS & - & THC & - & - & - & - \\
\hline \multirow{9}{*}{ (51) } & \multirow{9}{*}{ MS } & \multirow{6}{*}{$\begin{array}{c}\text { ESI positive mode, ionization } \\
\text { spray voltage }(5.2 \mathrm{kV}), \\
\text { turboIon spray }\left(450^{\circ} \mathrm{C}\right), \\
\text { nitrogen (as a turbo heating } \\
\text { gas, nebulizing gas, and curtain } \\
\text { gas) }\end{array}$} & CBD & \multirow{9}{*}{ - } & $315.2,193.2$ & \multirow{9}{*}{ - } & \multirow{9}{*}{-} \\
\hline & & & CBG & & $317.2,193.2$ & & \\
\hline & & & CBN & & $311.2,223.2$ & & \\
\hline & & & THC & & $315.2,193.2$ & & \\
\hline & & & $\Delta 8$-THC & & $315.2,193.2$ & & \\
\hline & & & $\mathrm{CBC}$ & & $315.2,193.2$ & & \\
\hline & & \multirow{3}{*}{$\begin{array}{l}\text { ESI negative mode, ionization } \\
\text { spray voltage }(-4.5 \mathrm{kV}), \\
\text { turboIon spray }\left(450^{\circ} \mathrm{C}\right), \\
\text { nitrogen (as a turbo heating } \\
\text { gas, nebulizing gas, and curtain } \\
\text { gas). For negative ionization, } \\
\text { post-column addition of a } 1 \% \\
\text { ammonia solution in the } \\
\text { extract was utilized at a flow } \\
\text { rate of } 50 \mu \mathrm{L} / \mathrm{min}\end{array}$} & THCA-D3 & & $346.2,302.1$ & & \\
\hline & & & CBDA & & $357.2,339.2$ & & \\
\hline & & & THCA & & $357.2,313.2$ & & \\
\hline
\end{tabular}




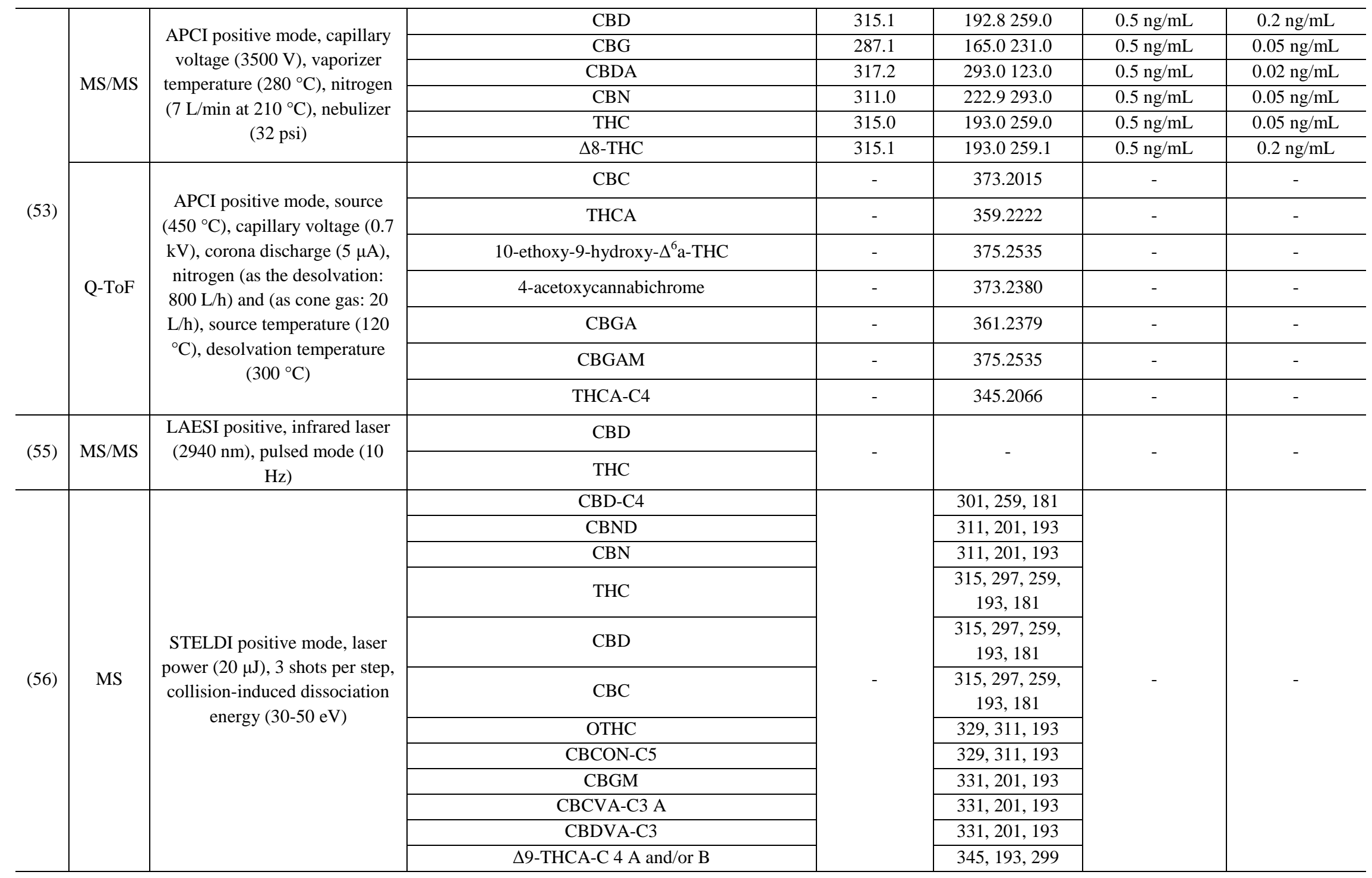




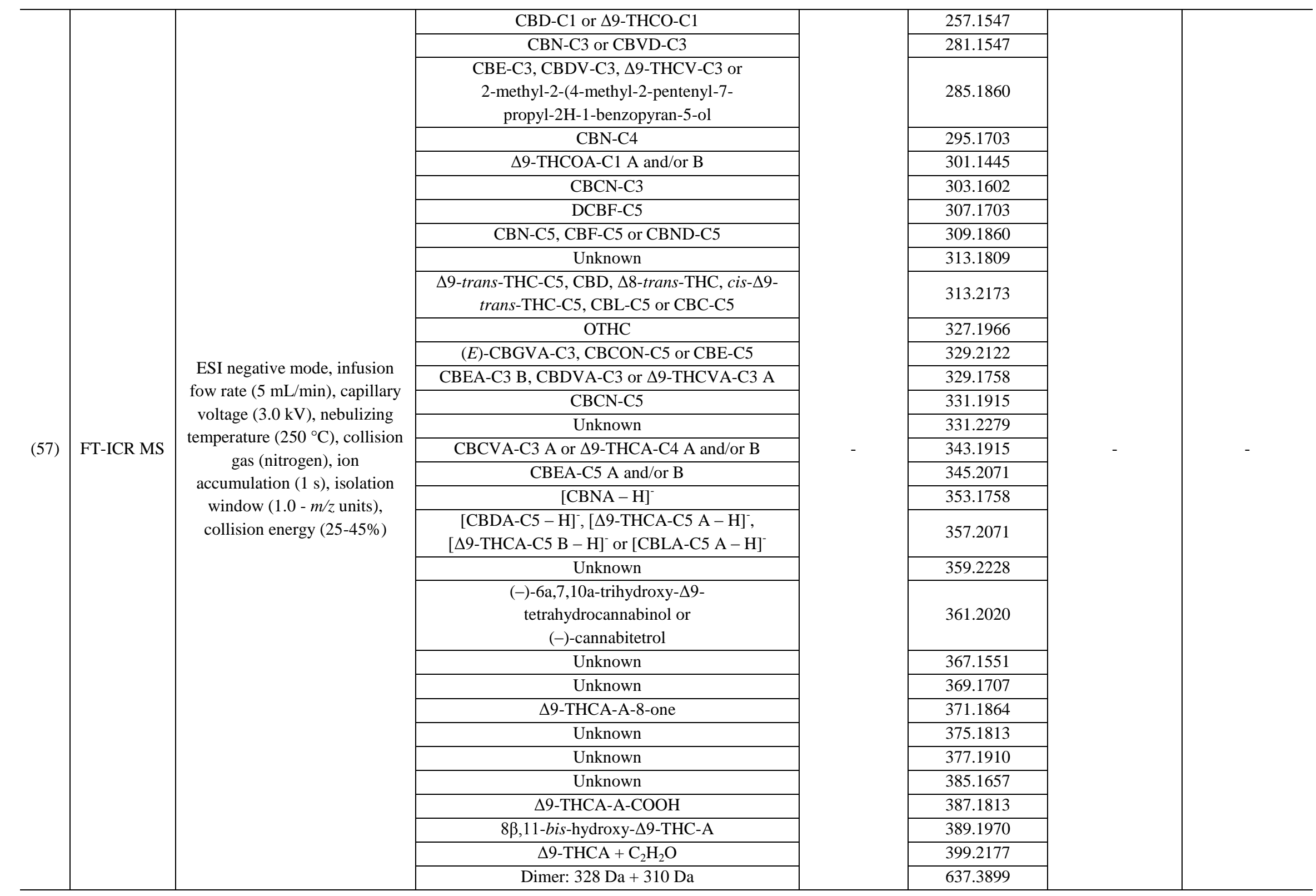


Drug Anal Res, 2017; 01, 1-23

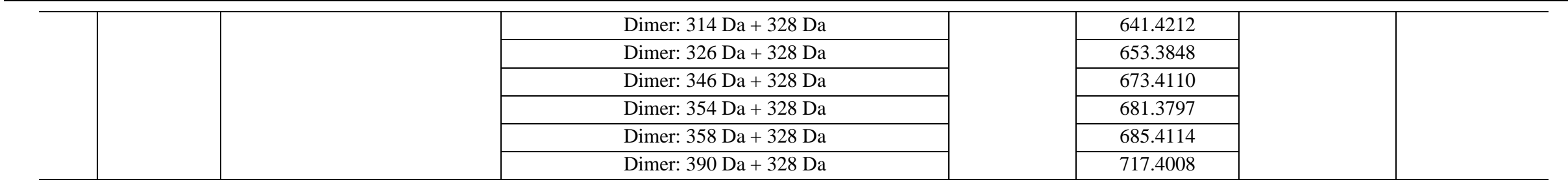

APCI: Atmospheric-pressure chemical ionization; $\mathrm{C}_{2} \mathrm{H}_{2} \mathrm{O}$ : ethenone; $\mathrm{CBC}$ : cannabichromene; $\mathrm{CBC}-\mathrm{C}$ : cannabichromene; $\mathrm{CBCA}$ : cannabichromenic acid; $\mathrm{CBCN}-\mathrm{C} 3$ : cannabichromanone-C3; CBCN-C5: cannabichromanone; CBCON-C5: cannabicoumaronone; CBCV: cannabichromevarin; CBCVA-C3 A: cannabichromevarinic acid A; CBD: cannabidiol; CBDA: cannabidiolic acid; CBDA-C5: cannabidiolic acid; CBD-C1: cannabidiorcol; CBDV: cannabidivarin; CBDV-C3: cannabidivarin; CBDVA-C3: cannabidivarinic acid; CBE-C3: (5aS,6S,9R,9aR)-C3-cannabielsoin; CBE-C5: $(5 \mathrm{a} S, 6 S, 9 R, 9 \mathrm{a} R)$-cannabielsoin; CBEA-C3 B: $(5 \mathrm{a} S, 6 S, 9 R S, 9 \mathrm{a} R)-9,10-\mathrm{C} 3$-cannabielsoic acid B; CBEA-C5 A and/or B: $(5 \mathrm{a} S, 6 S, 9 R, 9 \mathrm{a} R)$-cannabielsoic acid A and/or B; CBF: cannabifuran; CBG: cannabigerol; CBGA: cannabigerolic acid; CBGAM: cannabigerolic acid monomethylether; CBGM: cannabigerol monomethyl ether; CBGV: cannabigerovarin; (E)CBGVA-C3: cannabigerovarinic acid A; CBL: cannabicyclol; CBL-C5: cannabicyclol; CBLA: cannabicyclolic acid; CBLA-C5 A: cannabicyclolic acid A; CBLV: cannabicyclolvarin; CBN: cannabidiol; CBN-C5: cannabinol-C5; CBNA: cannabinolic acid; CBN-C3: cannabivarin; CBN-C4: cannabinol-C4; CBND: cannabinodiol; CBND-C5: cannabinodiol; CBT: cannabicitran; CBV: cannabivarin; CBVD-C3: cannabinodivarin; DCBF-C5: dehydrocannabifuran; $\Delta 9$-trans-THC-C5: (-)- $\Delta 9$-trans-(6aR,10aR)-tetrahydrocannabinol; $\Delta 8$-trans-THC: (-)- $\Delta 8$-trans$(6 \mathrm{a} R, 10 \mathrm{a} R)$-tetrahydrocannabinol; $\quad c i s-\Delta 9$-THC-C5: $\quad(-)-\Delta 9$-cis-(6aR,10aR)-tetrahydrocannabinol; $\Delta 9$-THCA: $\Delta 9$-tetrahydrocannabinolic acid; $\Delta 9$-THCA-C4 A and/or $\quad$ B: $\Delta 9$ tetrahydrocannabinolic acid-C4 A and/or B; $\Delta$ 9-THCA A and/or B: $\Delta$ 9-tetrahydrocannabinolic acid A and/or B; $\triangle 9$-THCA-A-COOH: $\Delta$ 9-THCOA-C1 A and/or B: $\Delta$ 9-tetrahydrocannabiorcolic acid A and/or B; $\triangle$ 9-THCA A-COOH: 11-nor-9-COOH- $\Delta$ 9-tetrahydrocannabinolic acid A; $\Delta$ 9-THCO-C1: tetrahydrocannabiorcol; $\Delta$ 9-THCV-C3: $\Delta$ 9-tetrahydrocannabivarin; $\Delta$ 9-THCVA-C3

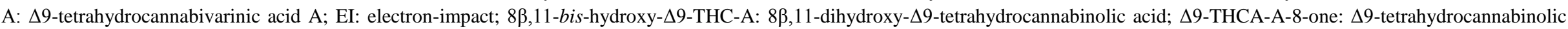
acid A-8-one; ESI: electrospray ionization; FT-ICR MS: Fourier transform ion cyclotron resonance mass spectrometry; LAESI: laser ablation electrospray ionization; MS/MS: tandem mass spectrometry; $m / z$ : mass-to-charge ratio; OTHC: 10-Oxo- $\Delta 6 a(10 a)$-tetrahydrocannabinol; Q-ToF: quadrupole-time-of-flight; STELDI: laser desorption ionization; THC: tetrahydrocannabinol; THCA: tetrahydrocannabinolic acid; THCV: tetrahydrocannabivarin; TOF: time-of-flight. 


\section{Conclusions}

The analytical methods for cannabis material published in the articles included in this systematic review showed the need to update the methodologies regarding the new potency of the drug, whether for its pharmacological potential, improvement of clinical conduct or quantification in forensic science. Although the findings of the literature review refer to an increased difficulty in cannabinoid separation by LC analysis than by GC analysis, the mass detector provides unambiguous identification of different overlapping compounds according to those described in the systematic articles included in this systematic review. In addition, it was possible to show that GC analysis are more used.

\section{Acknowledgements}

The authors would like to thank $\mathrm{CNPq}$ and CAPES (23038.007083/2014-91) for financial support and scholarships.

\section{References}

1. UNODC - United Nations Office on Drugs and Crime (2016) World Drug Report 2016. http://www.UNODC.org/doc/wdr2016/WORLD_D RUG_REPORT_2016_w eb.pdf (accessed on 04 September 2016).

2. WHO - World Health Organization (2016). The health and social effects of nonmedical cannabis use.

http://www.WHO.int/substance_abusepublications/ ms bcannabis.pdf (accessed on 04 September 2016).

3. Bruci, Z., Papoutsis, I., Athanaselis, S., Nikolaou, P., Pazari, E., Spiliopoulou, C., Vyshka, G. (2012) First systematic evaluation of the potency of Cannabis sativa plants grown in Albania, Forensic Science International, 222, 40-46.

4. Swift, W., Wong, A., Li, K.M., Arnold, J.C., McGregor, I.S. (2013) Analysis of Cannabis Seizures in NSW, Australia: Cannabis Potency and Cannabinoid Profile, PLoS ONE, 8, 1-9.

5. Aizpurua-Olaizola, O., Soydaner, U., Öztürk, E., Schibano, D., Simsir, Y., Navarro, P., Etxebarria, N., Usobiaga, A. (2016) Evolution of the Cannabinoid and Terpene Content during the Growth of Cannabis sativa Plants from Different Chemotypes, Journal of Natural Products, 79, 324331.

6. De Backer, B., Maebe, K., Verstraete, A.G., Charlier, C. (2012) Evolution of the Content of THC and Other Major Cannabinoids in Drug-Type
Cannabis Cuttings and Seedlings During Growth of Plants, Forensic Science International, 57, 918-922.

7. Broséus, J., Anglada, F., Esseiva, P. (2010). The differentiation of fibre- and drug type Cannabis seedlings by gas chromatography/mass spectrometry and chemometric tools, Forensic Science International, 200, 87-92.

8. Mariotti, K.C., Marcelo, M.C.A., Ortiz, R.S., Borille, B.T., Reis, M., Fett, M.S., Ferrão, M.F., Limberger, R.P. (2016) Seized cannabis seeds cultivated in greenhouse: A chemical study by gas chromatography-mass spectrometry and chemometric analysis, Science \& Justice, 56, 35-41.

9. UNODC - United Nations Office on Drugs and Crime (2009) Recommended methods for the identification and analysis of cannabis and cannabis products.

https://www.UNODC.org/documents/scientific/ST-

NAR-40-Ebook.pdf (accessed on 04 September 2016).

10. Trofin, I. G., Vlad, C.C., Noja, V.V., Dabija, G. (2012) Identification and Characterization of Special Types of Herbal Cannabis, UPB Scientific Bulletin, 74, 119-130.

11. Taschwer, M., Schmid, M.G. (2015) Determination of the relative percentage distribution of THCA and $\triangle 9$-THC in herbal cannabis seized in Austria Impact of different storage temperatures on stability, Forensic Science International, 254, 167-171.

12. Cadola, L., Broséus, J., Esseiva, P. (2013) Chemical profiling of different hashish seizures by gas chromatography-mass spectrometry and statistical methodology: A case report, Forensic Science International, 232, 24-27.

13. Pandohee, J., Holland, B.J., Li, B., Tsuzuki, T., Stevenson, P.G., Barnett, N.W., Pearson, J.R., Jones, O.A.H., Conlan, X.A. (2015) Screening of cannabinoids in industrial-grade hemp using twodimensional liquid chromatography coupled with acid potassium permanganate chemiluminescence detection, Journal of Separation Science, 38, 2024 2032.

14. Ambach, L., Penitschka, F., Broillet, A., König, S., Weinmann, W., Bernhard, W. (2014) Simultaneous quantification of delta-9-THC, THC-acid A, CBN and $\mathrm{CBD}$ in seized drugs using HPLC-DAD, Forensic Science International, 243, 107-111.

15. Rotherham, D., Harbison, S.A. (2011) Differentiation of drug and non-drug Cannabis using a single nucleotide polymorphism (SNP) assay, Forensic Science International, 207, 193-197. 
16. Cascini, F., Passerotti, S., Martello, S. (2012) A real-time PCR assay for the relative quantification of the tetrahydrocannabinolic acid (THCA) synthase gene in herbal Cannabis samples, Forensic Science International, 217, 134-138.

17. Moher, D., Liberati, A., Tetzlaff, J., Altman, D.G., Group, P. (2010) Preferred reporting items for systematic reviews and meta-analyses: the PRISMA statement, International Journal of Surgery, 8, 336341 .

18. Small, E., Cronquist, A. (1976) A Practical and Natural Taxonomy for Cannabis, Taxon, 25, 405435 .

19. Small, E. (2016) Evolution and Classification of Cannabis sativa (Marijuana, Hemp) in Relation to Human Utilization, Botanical Review, 81, 189-294.

20. Sawler, J., Stout, J.M., Gardner, K.M.., Hudson, D., Vidmar, J., Butler, L., Page, J.E., Myles, S. (2015) The Genetic Structure of Marijuana and Hemp, PLOS ONE, 10, 1-9.

21. Amaducci, S., Scordia, D., Liu, F.H., Zhang, Q., Guo, H., Testa, G., Cosentino, S.L. (2015) Key cultivation techniques for hemp in Europe and China, Industrial Crops and Products, 68, 2-16.

22. Gloss, D. (2015) An Overview of Products and Bias in Research, Neurotherapeutics, 12, 731-734.

23. Salentijn, E.M.J., Zhang, Q., Amaducci, S., Yang, M., Trindade, L.M. (2015) New developments in fiber hemp (Cannabis sativa L.) breeding, Industrial Crops and Products, 68, 32-41.

24. Elsohly, M.A., Slade, D. (2005) Chemical constituents of marijuana: The complex mixture of natural cannabinoids, Life Sciences, 78, 539-548.

25. Radwan, M.M., ElSohly, M.A., El-Alfy, A.T., Ahmed, S.A., Slade, D., Husni, A.S., Manly, S.P., Wilson L., Seale S., Cutler, S.J., Ross, S.A. (2015) Isolation and Pharmacological Evaluation of Minor Cannabinoids from High-Potency Cannabis sativa, Journal of Natural Products, 78, 1271-1276.

26. Russo, E.B. (2011) Taming THC: potential cannabis synergy and phytocannabinoid-terpenoid entourage effects, British Journal of Pharmacology, 163, 1344-1364.

27. Small, E., Naraine, S.G.U. (2016) Size matters: evolution of large drug-secreting resin glands in elite pharmaceutical strains of Cannabis sativa (marijuana), Genetic Resources and Crop Evolution, 63, 349-359.
28. Onofri, C., De Meijer, E.P.M., Mandolino, G. (2015) Sequence heterogeneity of cannabidiolicand tetrahydrocannabinolic acid-synthase in Cannabis sativa L. and its relationship with chemical phenotype, Phytochemistry, 116, 57-68.

29. Rogeberg, O., Elvik, R. (2016). The effects of cannabis intoxication on motor vehicle collision revisited and revised. Addiction, 111, 1348-1359.

30. Evans, D.G. (2013). The Economic Impacts Of Marijuana Legalization, The Journal of Global Drug Policy and Practice, 1-39.

31. ElSohly, M.A., Mehmedic, Z., Foster, S. Gon, C., Chandra, S., Church, J.C. (2016) Changes in cannabis potency over the last two decades (19952014) - Analysis of current data in the United States. Biological Psychiatry, 79, 613-619.

32. Crippa, J.A., Lacerda, L.T.A., Amaro, E., Busatto Filho, G., Zuardi, A.W., Bressan, R.A. (2005) Efeitos cerebrais da maconha: resultados dos estudos de neuroimagem. Revista Brasileira de Psiquiatria, 27, 70-78.

33. Freeman, T.P., Winstock, A.R. (2015) Examining the profile of high-potency cannabis and its associatiion with severety of cannabis dependence, Psychological Medicine, 45, 3181-3189.

34. Di Forti, M., Marconi, A., Carra, E., Fraletta, S., Trotta, A., Bonomo, M., Murray, R.M. (2015) Proportion of patients in soth London with first episode psychosis attributable to use of highpotency cannabis: a case control study, The Lancet Psychiatry, 2, 233-238.

35. Hall, W. (2015) What has research ove the past two decadesrevelated about the adverse health effects of recreational cannabis use?, Addiction, 110, 19-35.

36. Tipparat, P., Kunkaew, W., Julsrigival, S., Pinmanee, S., Natakankitkul, S. (2014) Classification of Cannabis Plants Grown in Northern Thailand using Physico-Chemical Properties, Journal of Natural Sciences Research, 4, 46-54.

37. Vanhove, W., Van Damme, P., Meert, N. (2011) Factors determining yield and quality of illicit indoor cannabis (Cannabis spp.) production, Forensic Science International, 212, 158-163.

38. Mander, L., Liu, H-W., (2010) Comprehensive Natural Products II: Chemistry and Biology, Volume 1, 1st Edition, Elsevier Science.

39. Ahmad, U.K., Muniandy, Y., Hassan, M.S. (2014) Physical Analysis and Chemical Profiling of Illicit 
Herbal Cannabis using Multivariate Analysis, Malaysian Journal of Forensic Sciences, 5, 26-34.

40. Giese, M.W., Lewis, M.A., Giese, L., Smith, K.M. (2015) Development and Validation of a Reliable and Robust Method for the Analysis of Cannabinoids and Terpenes in Cannabis, Drug Formulations and Clinical Methods, 98, 1503-1522.

41. Hoffmann, E., Stroobant, V. (2007) Mass Spectrometry: Principles and Applications, 3rd Edition, John Wiley \& Sons Inc, London.

42. Nikolaev, E.N., Kostyukevich, Y.I., Vladimirov, G.N. (2016) Fourier transform ion cyclotron resonance (ft icr) mass spectrometry: theory and simulations, Mass Spectrometry Reviews, 35, 219259.

43. Chandra, S., Lata, H., Mehmedic, Z., Khan, I.A., ElSohly, M.A. (2010) Assessment of Cannabinoids Content in Micropropa- gated Plants of Cannabis sativa and Their Comparison with Conventionally Propagated Plants and Mother Plant during Developmental Stages of Growth, Planta Medica, 76, 743-750.

44. Fischedick, J.T., Hazekamp, A., Erkelens, T., Choi, Y.H., Verpoorte, R. (2010) Metabolic fingerprinting of Cannabis sativa L., cannabinoids and terpenoids for chemotaxonomic and drug standardization purposes, Phytochemistry, 78, 2058-2073.

45. Knight, G., Hansen, S., Connor, M., Poulsen, H., McGovern, C., Stacey, J. (2010) The results of an experimental indoor hydroponic Cannabis growing study, using the 'Screen of Green' (ScrOG) method-Yield, tetrahydrocannabinol (THC) and DNA analysis, Forensic Science International, 202, 36-44.

46. Lata, H., Chandra, S., Khan, I.A., ElSohly, M.A. (2010) High Frequency Plant Regeneration from Leaf Derived Callus of High $\Delta 9$ Tetrahydrocannabinol Yielding Cannabis sativa L., Planta Medica, 76, 1629-1633.

47. Mehmedic, Z., Chandra, S., Slade, D., Denham, H., Foster, S., Patel, A.S., Ross, S.A., Khan, I.A., ElSohly, M.A. (2010) Potency Trends of $\Delta^{9}$-THC and Other Cannabinoids in Confiscated Cannabis Preparations from 1993 to 2008*, Journal of Forensic Sciences, 55, 1209-1217.

48. Hazekamp, A., Fischedick, J.T. (2012) Cannabis from cultivar to chemovar, Drug Testing and Analysis, 4, 660-667.

49. Lata, H., Chandra, S., Techen, N., Khan, I.A., ElSohly, M.A. (2011) Molecular analysis of genetic fidelity in Cannabis sativa L. plants grown from synthetic (encapsulated) seeds following in vitro storage, Biotechnology Letters, 33, 2503-2508.

50. Tipparat, P., Natakankitkul, S., Chamnivikaipong, P., Chutiwat, S. (2012) Characteristics of cannabinoids composition of Cannabis plants grown in Northern Thailand and its forensic application, Forensic Science International, 215, 164-170.

51. Happyana, N., Agnolet, S., Muntendam, R., Van Dam, A., Schneider, B., Kayser, O. (2013) Analysis of cannabinoids in laser-microdissected trichomes of medicinal Cannabis sativa using LCMS and cryogenic NMR, Phytochemistry, 87, 51-59.

52. Ameur, S., Haddou, B., Derriche, Z., Canselier, J.P., Gourdon, C. (2013) Cloud point extraction of $\Delta 9$ tetrahydrocannabinol from cannabis resin, Analytical and Bioanalytical Chemistry, 405, 31173123.

53. Aizpurua-Olaizola, O., Omar, J., Navarro, P., Olivares, M., Etxebarria, N., Usobiaga, A. (2014) Identification and quantification of cannabinoids in Cannabis sativa L. plants by high performance liquid chromatography-mass spectrometry, Analytical and Bioanalytical Chemistry, 406, 75497560 .

54. Peschel, W., Politi, M. (2015) ${ }^{1} \mathrm{H}$ NMR and HPLC/DAD for Cannabis sativa L. chemotype distinction, extract profiling and specification, Talanta, 140, 150-165.

55. Deimler, R.E., Razunguzwa, T.T., Reschke, B.R., Walsh, C.M., Powell M.J., Jackson, G.P. (2014) Direct analysis of drugs in forensic applications using laser ablation electrospray ionization-tandem mass spectrometry (LAESI-MS/MS), Analytical Methods, 6, 4810-4817.

56. Eiras, M.M., De Oliveira, D.N., Ferreira, M.S., Benassi, M., Cazenave, S.O.S., Catharino, R.R. (2014) Fast fingerprinting of cannabinoid markers by laser desorption ionization using silica plate extraction, Analytical Methods, 6, 1350-1352.

57. Nascimento, I.R., Costa, H.B., Souza, L.M., Soprani, L.C., Merlo, B.B., Romão, W. (2015) Chemical identification of cannabinoids in street marijuana samples using electrospray ionization FTICR mass spectrometry, Analytical Methods, 7, 1415-1424.

58. Srivastava, A., VK, Y. (2013) Microscopical and Chemical Study of Cannabis sativa, Forensic Research, 5, 1-6. 
59. Balbino, M.A., De Oliveira, L.S., Eleoterio, I.C., Oiye, E.N., Ribeiro, M.F.M., McCord, B.R., Ipolito, A.J., De Oliveira, M.F. (2016) The Application of Voltammetric Analysis of $\Delta^{9}$-THC for the Reduction of False Positive Results in the Analysis of Suspected Marijuana Plant Matter, Journal of Forensic Sciences, 1-7.

60. Tanaka, H. (2011) Immunochemical Approach Using Monoclonal Antibody against $\Delta^{9}$ Tetrahydrocannabinolic Acid (THCA) to Discern Cannabis Plants and to Investigate New Drug Candidates, Current Drug Discovery Technologies, 8, 3-15.

61. Lata, H., Chandra, S., Techen, N. Khan, I.A., ElSohly, M.A. (2010) Assessment of the Genetic Stability of Micropropagated Plants of Cannabis sativa by ISSR Markers, Planta Medica, 76, 97100.

62. Allgeier, L., Hemenway, J., Shirley, N., LaNier, T., Coyle, H.M. (2011) Field Testing of Collection Cards for Cannabis sativa Samples With a Single Hexanucleotide DNA Marker, Journal of Forensic Sciences, 56, 1245-1249.

63. Sutipatanasomboon, A., Panvisavas, N. (2011) Discrimination of 'fiber-type' and 'drug-type' Cannabis sativa L.by fluorescent duplex PCR, Forensic Science International: Genetics Supplement Series 3, e522-e523. 